\title{
THE IMPACT OF STAMP DUTY REDUCTIONS ON DEMAND IN THE PERTH HOUSING MARKET
}

\author{
GREG COSTELLO \\ Curtin University
}

\begin{abstract}
In 2004, the Western Australian state government announced and implemented policy incentives for first-home buyers in the form of either total conveyance duty (stamp duty) exemptions or significant reductions for specified price bands of housing. This paper analyses the impact of this policy on demand in the Perth housing market. Results confirm an immediate and significant impact on demand in both price segments that were the target of policy and to a lesser extent also within price segments that were not the target of policy. Results also confirm some important information diffusion or 'news' effects. The release of information two months prior to enactment of the policy lead to a pronounced decline in demand for cheaper housing and also in other price segments prior to enactment of the policy.
\end{abstract}

Keywords: Housing, stamp duty, demand, policy influences.

\section{INTRODUCTION}

On 7 May 2004, the Western Australian (WA) state government announced a set of specific policy incentives for first-home buyers to be introduced on 1 July 2004. The main thrust of the policy changes were either total conveyance duty (stamp duty) exemptions or significant reductions for specified price bands of housing and vacant land. The introduction of these policy incentives presents the opportunity for empirical research relating to the impact of the policy on both demand and prices in housing markets and the impact of new information on demand and prices within housing markets. This paper examines first how the May 2004 announcement of the impending policy change impacted on demand for housing prior to July 1, 2004 and second how the enactment of the policy impacted on demand within the Perth housing market after July 1, 2004.

The 2004 policy incentives targeted at WA first-home buyer markets can be summarised:

- First-home purchases of less than $\$ 220,000$ became free of conveyance duty and a reduced rate of conveyance duty became available for first-home purchases up to $\$ 300,000$. 
- Purchases of vacant land by first-home buyers of less than $\$ 100,000$ became free of conveyance duty and a reduced rate became available for purchases up to $\$ 150,000 .^{1}$

\section{MOTIVATION AND RELATED LITERATURE}

The introduction of these policy changes presents the opportunity to examine empirically the influence of an important housing policy initiative and the impact of important information or 'news' within a large urban housing market. With Australia having one of the world's highest levels of home ownership, a major proportion of Australian individual wealth is kept in the form of housing stock and a large proportion of personal consumption expenditure is devoted to housing. In this environment, housing affordability is an important economic and political concern. During the period 2002-2006, information and commentary concerning housing markets in Australian capital cities has appeared frequently in the popular press and it is widely acknowledged that Australia has experienced a significant housing boom during this period. The housing boom has identified several areas of concern for housing policy and the general macro-economy. The issues of housing affordability and a potential 'generational wealth divide' caused by increasing house prices are topical subjects attracting frequent media commentary and political debate.

An indication of the importance attached to housing market activity during this period was the conference on "Asset Prices and Monetary Policy" hosted by the Reserve Bank of Australia in Sydney 18-19 August 2003. At this conference, several noted international authors (Case and Shiller, 2003) presented papers relevant to housing market activity and its impact on the macro-economy.

Over the years, a number of housing policies at State and Federal levels in Australia have been targeted at the expansion of home ownership. While not its primary purpose, stamp (conveyance) duty is a taxation instrument at state level that can be used by state governments to intervene in housing markets by directly influencing the level of transaction costs to home buyers.

There is a considerable international literature examining the influence of taxation policies in housing markets. An established neo-classical view is that rapidly expanding housing markets are influenced heavily by demand for newer properties and effective housing

\footnotetext{
${ }^{1}$ In monetary terms, this stamp duty exemption represents a saving of $\$ 7,000$ for a first-home buyer of a $\$ 220,000$ house at 1 July 2004 . The tax-free threshold has subsequently been lifted to $\$ 250,000$. In addition to stamp duty exemptions, eligible first-home owners could also receive a first-home owner grant (FHOG) of \$7,000. At $1 \mathrm{July}$ 2004, the FHOG, a federal government initiative had been in existence for some time and did not constitute new information.
} 
policy should promote equilibrium in housing markets by stimulating supply of new housing since the short-run supply of housing is inelastic (Poterba, 1984).

It is important to acknowledge the wide variation in international practice in the use of taxation measures in housing policy. Wood (1990) discussed a number of taxation policy initiatives in European housing markets that were designed to encourage private sector investment and argued that these policies had the ability to benefit both rental and owneroccupied tenures. More recently, Berry, McGreal, Stevenson and Young (2001) examine the impact of taxation reforms in the Dublin housing market and acknowledge that significant increases on the demand side for housing are created by macro economic influences such as increasing population, employment levels, wages and low interest rates. In Ireland during the 1990's, these demand forces exceeded the supply side response capacity with a resultant rapid increase in prices. It is in this environment that governments can either revert to fiscal policy or taxation measures to influence both demand and supply in housing markets, with the influence generally being most pronounced on the demand side.

In the UK, much of the literature has focused upon the influence of the now defunct mortgage tax relief measures for owner-occupiers. Berry et al (2001) point out that this policy was largely ineffective, resulting in higher house prices and little change in the supply of housing. They argue that taxation measures such as increases in stamp duty offer an alternative mechanism to the use of interest rates in 'dampening' down speculative housing markets, as occurred in Ireland during the 1990's.

This international variation in approaches to taxation policy in housing markets makes the 2004 WA policy initiatives an individual and useful case study. In contrast to other countries, Australia has never had a mortgage tax relief scheme for owner-occupiers and if such a scheme was to be introduced, it would need to be promoted at a Federal level.

Stamp duty is a state based tax and in the 2000-2004 period, the increases in stamp duty levels had been the focus of considerable media commentary and political debate in WA. The initiative to either exempt or significantly reduce levels of stamp duty for first-home owners within specific price bands represents an individual policy initiative with the potential to provide useful information on its effects in a number of urban and regional housing markets throughout WA.

The value and influence of information in asset markets has been a key theme in the finance literature since Fama's (1970) seminal contribution. There is a considerable literature examining the impact of announcements on real estate values. Much of this literature examines the impact of announcements on securitized real estate assets. Schwann and Chau (2003) summarise much of this literature in their study of price discovery relationships between securitized and direct real estate markets in Hong Kong. They 
suggest that some changes in price discovery effects may be linked to anti-speculative measures introduced in 1994 to curb speculation in the Hong Kong residential market.

There remains a paucity of studies examining the influence of announcements in Australian housing markets. The 2004 Western Australian policy initiatives provide an opportunity to examine how the introduction of important new information can influence both demand and prices in housing markets. This paper contributes to the considerable housing market efficiency literature (for a comprehensive review of early literature, see Gatzlaff and Tirtiroglu (1995); for a more recent discussion, see Leung, Leong and Wong (2006)). Efficiency in the real estate market is desirable for the same reasons that efficiency is desirable in other product or securities markets. If prices provide accurate signals for purchase or disposition of real estate assets, then they facilitate the correct allocation of scarce financial resources.

The processes by which households exchange housing units over time and thereby move between different price and location segments is important in analysing housing market efficiency in the widest sense. This process encompasses important issues of informational, allocative and operational efficiency. The theory of efficient housing markets suggests that in an aggregate housing market, the information diffusion processes will exist whereby housing units can be exchanged with an absence of market failure in all price-location segments. The time lag (almost two months) between the announcement and the enactment of the 2004 WA policy provides an opportunity to conduct an instructive 'event' study as to how this information influenced changes in demand and prices, both within first-home submarkets and the aggregate Perth housing market.

These policy initiatives and the quality of data available for analysis provide the opportunity to complete an instructive empirical analysis of the impact of the policy initiatives on the demand for housing in the Perth metropolitan region.

\section{DATA AND METHODOLOGY}

\section{The empirical study}

The empirical study uses house sales for the period June 1988 to June 2005 for the entire Perth metropolitan region. This data was obtained from the WA Valuation Land and Property Database. This data service provides a rich source of micro-data, comprising a complete record of the demand side of the Perth housing market for the sample period. The empirical study focuses upon two key research questions:

1. Did the announcement of proposed stamp duty changes in the relevant price segments impact upon demand for those segments and in the aggregate Perth housing market prior to July 1, 2004? 
2. What was the impact on demand in these price segments and in the aggregate Perth housing market post July 1 ?

Assuming that participants in the Perth housing market acted rationally in response to the value of information, then intuition suggests that it is likely that the announcement of the policy prior to enactment on 1 July would influence both the demand and supply of housing. In addition, it is likely that in some sub-markets, a two-tier market might exist whereby different motivations existed for the different classes of market participants (first and non-first-home buyers and sellers). The a priori expectation is that after the policy announcement on 7 May, first-home buyers would be discouraged from purchasing prior to 1 July. This is due to the significant cash benefit in the form of reduced transaction costs available after 1 July.

Given these market conditions, it is likely that demand for housing within the relevant price segments would decline in the period prior to 1 July. In a similar manner, sellers of these properties would be encouraged to defer sale until after 1 July when the impact of the policy might encourage buyers to pay higher prices since they were saving on transaction costs. Given this scenario and rational expectations, it is likely that after 1 July, there would be an increase in demand in first-home buyer markets.

An associated but less clear implication of the policy initiatives is the extent to which changes in demand in first-home buyer markets would impact on the aggregate market and other house price segments. The contingent nature of housing markets means that many individual sales are components of 'chains' of transactions. In this environment, first-home sales are an important part of these chains since many of these sellers are 'trading up' in the market. Changes in demand and supply in first-home (cheaper) price segments are likely to also impact on other price segments. For this reason, the tests that follow include results for the aggregate market, first-home price bands and 'other' sales.

Research questions 1 and 2 above focus upon tests of change in demand in specific time periods either before or after 1 July 2004. To test these questions, the research design uses a specific method of housing market disaggregation determined by price levels through the sample period. This involves deflating the relevant 1 July 2004 house price limit of $\$ 220,000$ to identify comparable price segments through time that are the target of the policy initiatives. The deflation procedure uses a weighted repeat-sales (WRS) index constructed using the Case and Shiller (1989) method. This index model has been extensively applied to analysis of the Perth housing market in previous studies. ${ }^{2}$ Chart 1 illustrates the trend of house price changes in Perth for the period 1988-2005 from the relevant house price index used in the deflation procedure.

${ }^{2}$ Costello (2000) provides a comprehensive overview of this index model with relevant index diagnostics. 
The consistent increase in house prices in the period 2000-2005 is clearly evident in Chart 1. The relevant index numbers used in the deflation procedure are available in Table 1 and confirm that the increase in house price for the full sample period 1988-2005 is about 180\% and in the five year period $2000-2005$ about $83 \%$.

Chart 1: House prices: Perth: 1988 - 2005

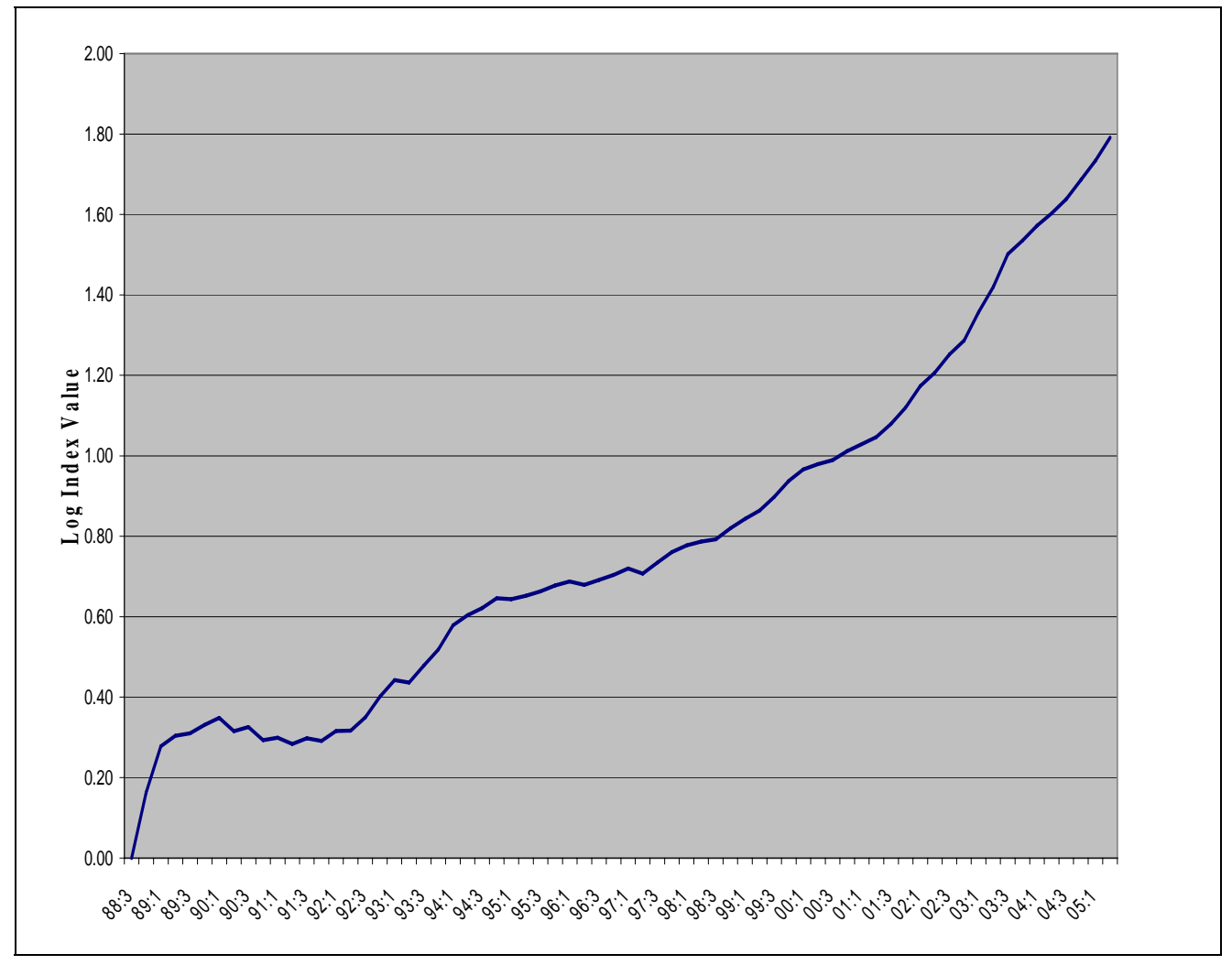

The objective of this deflation procedure is to specify house price sub-markets through time that should be approximately comparable to the 2004 target sub-markets for the policy initiatives. To identify a relevant price sub-market through the sample period, the logarithmic WRS index is used as follows:

$$
P t=\frac{220,000}{\exp (W R S: Q 3: 04-W R S: Q t))}
$$

where:

$P t$ is the deflated price level at quarter $t$. 
WRS:Q3:04: is the constant logarithmic index level of 1.638 measured at quarter 3, 2004.

WRS:Qt: is the variable logarithmic level for the relevant quarter $t$ where $P t$ is to be estimated.

Table 1 provides summary data for estimated index levels and first-home owner price bands through the sample period. As an example, from equation (1), the estimated firsthome owner price band for Q3:03 to Q2:04 is estimated as follows: $192,000 \approx 220,000$ / $\exp (1.638-1.502)$. Note that some small rounding adjustments are needed to round prices off to the nearest thousand dollars to reflect the reality of negotiated prices in housing markets.

Table 1 demonstrates how quarterly demand series are constructed according to the volume of transactions in the aggregate Perth housing market, but if aggregate data is used, there is a problem of a limited number of observations in the time series. This issue is overcome by further disaggregating the data into 19 spatial regions determined by Local Government Authority (LGA) and using a 'stacked' data procedure to improve the explanatory power of statistical tests by increasing the number of observations on the relevant quarterly periods of interest.

Before testing for changes in demand, seasonal and trend influences must be addressed. To recognise trend and seasonal influences in demand, a centred moving average (CMA) procedure is used to construct a variable $\Phi$ that is the ratio of the volume of transactions in a quarterly period to the CMA for the annual period. From Table 1, the new variable $\Phi$ can be used in parametric statistical testing methods to test whether demand in a quarterly period is significantly different than for other quarterly periods. Costello (2001) used similar tests to identify clear seasonal trends within the aggregate Perth housing market. ${ }^{3}$

After recognizing seasonal influences, research questions 1 and 2 focus upon measuring the impact on demand of changes in levels of stamp duty at 1 July 2004. The quarterly periods of interest for these tests are Q2:2004 and Q3:2004 (highlighted in Table 1). If the impact of events is as expected, demand in Q2 should be lower than for previous years and in Q3 demand should be higher. The variation in demand in these periods is also tested with the parametric one-sample $t$ test. In these tests, the ratio variable $\Phi$ from Table 1 is used to test the null hypothesis that the mean $\Phi$ for the relevant quarter (Q2 or Q3:2004) is the same as the mean $\Phi$ for the relevant quarters for the full time series 1988-2005 and also for a shorter time series 1999-2005. The results for these tests on seasonality and policy influences on demand are shown in Table 2.

\footnotetext{
${ }^{3}$ Costello (2001) identifies the first quarter (Jan-Mar) having the highest demand and the second and third quarters having the lowest demand. The fourth quarter is characterised by a distinct 'christmas effect' with a marked decline in demand during December.
} 
Table 1: Perth house sales: 1988-2005: summary data

\begin{tabular}{|c|c|c|c|c|c|c|c|c|c|c|}
\hline \multicolumn{6}{|c|}{ Summary Data } & \multicolumn{3}{|c|}{$\begin{array}{l}\text { Total sales moving } \\
\text { average example }\end{array}$} & \multicolumn{2}{|c|}{$\Phi$ Ratios } \\
\hline$\frac{\overline{0}}{\frac{0}{0}}$ & 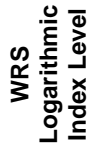 & 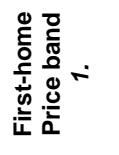 & 丞造 & 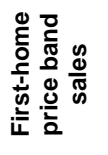 & 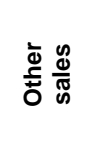 & 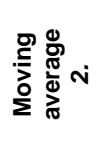 & 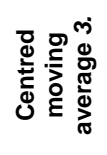 & 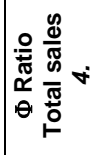 & 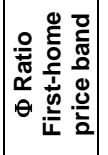 & 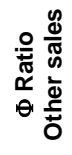 \\
\hline $88: Q 3$ & 0.000 & 43,000 & 7,450 & 714 & 6,736 & & & & & \\
\hline 88:Q4 & 0.163 & & 8,341 & 631 & 7,710 & 6,728 & & & & \\
\hline 89:Q1 & 0.278 & & 6,902 & 270 & 6,632 & 6,037 & 6,382 & 1.08 & 0.68 & 1.11 \\
\hline 89:Q2 & 0.304 & & 4,217 & 141 & 4,076 & 5,054 & 5,546 & 0.76 & 0.45 & 0.78 \\
\hline 89:Q3 & 0.310 & 58,000 & 4,689 & 365 & 4,324 & 5,082 & 5,068 & 0.93 & 1.11 & 0.91 \\
\hline 89:Q4 & 0.331 & & 4,409 & 349 & 4,060 & 5,517 & 5,300 & 0.83 & 0.76 & 0.84 \\
\hline 90:Q1 & 0.348 & & 7,012 & 660 & 6,352 & 6,148 & 5,833 & 1.20 & 1.08 & 1.22 \\
\hline 90:Q2 & 0.315 & & 5,959 & 785 & 5,174 & 6,798 & 6,473 & 0.92 & 1.04 & 0.91 \\
\hline 90:Q3 & 0.325 & 59,000 & 7,213 & 915 & 6,298 & 6,923 & 6,861 & 1.05 & 1.04 & 1.05 \\
\hline $90: Q 4$ & 0.293 & & 7,007 & 984 & 6,023 & 7,496 & 7,210 & 0.97 & 1.03 & 0.96 \\
\hline 91:Q1 & 0.299 & & 7,514 & 985 & 6,529 & 7,519 & 7,507 & 1.00 & 0.98 & 1.00 \\
\hline 91:Q2 & 0.283 & & 8,251 & 1,117 & 7,134 & 7,146 & 7,332 & 1.13 & 1.15 & 1.12 \\
\hline 91:Q3 & 0.298 & 58,000 & 7,302 & 934 & 6,368 & 7,373 & 7,260 & 1.01 & 0.99 & 1.01 \\
\hline 91:Q4 & 0.291 & & 5,517 & 728 & 4,789 & 7,543 & 7,458 & 0.74 & 0.78 & 0.73 \\
\hline 92:Q1 & 0.316 & & 8,422 & 1,000 & 7,422 & 7,813 & 7,678 & 1.10 & 1.08 & 1.10 \\
\hline 92:Q2 & 0.316 & & 8,930 & 993 & 7,937 & 8,459 & 8,136 & 1.10 & 1.06 & 1.10 \\
\hline 92:Q3 & 0.350 & 61,000 & 8,384 & 1,005 & 7,379 & 8,575 & 8,517 & 0.98 & 1.11 & 0.97 \\
\hline 92:Q4 & 0.401 & & 8,101 & 776 & 7,325 & 8,684 & 8,630 & 0.94 & 0.94 & 0.94 \\
\hline 93:Q1 & 0.442 & & 8,884 & 694 & 8,190 & 9,114 & 8,899 & 1.00 & 0.85 & 1.01 \\
\hline 93:Q2 & 0.436 & & 9,368 & 687 & 8,681 & 9,563 & 9,339 & 1.00 & 0.78 & 1.03 \\
\hline 93:Q3 & 0.479 & 69,000 & 10,102 & 1,207 & 8,895 & 10,545 & 10,054 & 1.00 & 1.23 & 0.98 \\
\hline 93:Q4 & 0.518 & & 9,899 & 1,066 & 8,833 & 10,712 & 10,629 & 0.93 & 0.97 & 0.93 \\
\hline 94:Q1 & 0.579 & & 12,811 & 1,241 & 11,570 & 10,634 & 10,673 & 1.20 & 1.04 & 1.22 \\
\hline 94:Q2 & 0.604 & & 10,036 & 1,061 & 8,975 & 10,187 & 10,410 & 0.96 & 0.83 & 0.98 \\
\hline 94:Q3 & 0.621 & 80,000 & 9,790 & 1,638 & 8,152 & 8,958 & 9,572 & 1.02 & 1.25 & 0.99 \\
\hline 94:Q4 & 0.646 & & 8,110 & 1,321 & 6,789 & 8,383 & 8,670 & 0.94 & 0.99 & 0.93 \\
\hline 95:Q1 & 0.643 & & 7,895 & 1,217 & 6,678 & 7,932 & 8,157 & 0.97 & 0.91 & 0.98 \\
\hline 95:Q2 & 0.652 & & 7,735 & 1,241 & 6,494 & 7,780 & 7,856 & 0.98 & 0.94 & 0.99 \\
\hline 95:Q3 & 0.663 & 83,000 & 7,986 & 1,501 & 6,485 & 8,039 & 7,909 & 1.01 & 1.09 & 0.99 \\
\hline 95:Q4 & 0.678 & & 7,502 & 1,358 & 6,144 & 8,018 & 8,029 & 0.93 & 0.95 & 0.93 \\
\hline 96:Q1 & 0.688 & & 8,932 & 1,582 & 7,350 & 7,821 & 7,920 & 1.13 & 1.10 & 1.13 \\
\hline 96:Q2 & 0.679 & & 7,653 & 1,321 & 6,332 & 7,884 & 7,853 & 0.97 & 0.91 & 0.99 \\
\hline 96:Q3 & 0.691 & 85,000 & 7,197 & 1,449 & 5,748 & 7,267 & 7,576 & 0.95 & 1.03 & 0.93 \\
\hline $96: Q 4$ & 0.704 & & 7,754 & 1,489 & 6,265 & 7,553 & 7,410 & 1.05 & 1.07 & 1.04 \\
\hline 97:Q1 & 0.720 & & 6,465 & 1,191 & 5,274 & 8,019 & 7,786 & 0.83 & 0.81 & 0.84 \\
\hline 97:Q2 & 0.707 & & 8,796 & 1,574 & 7,222 & 8,422 & 8,220 & 1.07 & 1.01 & 1.08 \\
\hline 97:Q3 & 0.734 & 89,000 & 9,059 & 1,865 & 7,194 & 9,354 & 8,888 & 1.02 & 1.11 & 1.00 \\
\hline $97: Q 4$ & 0.761 & & 9,369 & 1,751 & 7,618 & 9,635 & 9,494 & 0.99 & 0.98 & 0.99 \\
\hline 98:Q1 & 0.777 & & 10,192 & 1,832 & 8,360 & 9,581 & 9,608 & 1.06 & 0.99 & 1.08 \\
\hline 98:Q2 & 0.787 & & 9,918 & 1,845 & 8,073 & 9,620 & 9,601 & 1.03 & 0.97 & 1.05 \\
\hline 98:Q3 & 0.792 & 94,000 & 8,845 & 2,012 & 6,833 & 10,174 & 9,897 & 0.89 & 1.00 & 0.87 \\
\hline 98:Q4 & 0.820 & & 9,525 & 2,037 & 7,488 & 10,409 & 10,292 & 0.93 & 0.95 & 0.92 \\
\hline
\end{tabular}

Pacific Rim Property Research Journal, Vol 12, No 2 


\begin{tabular}{|c|c|r|r|r|r|r|r|r|r|c|}
\hline 99:Q1 & 0.843 & & 12,407 & 2,477 & 9,930 & 10,953 & 10,681 & 1.16 & 1.08 & 1.18 \\
\hline 99:Q2 & 0.864 & & 10,860 & 2,179 & 8,681 & 11,238 & 11,096 & 0.98 & 0.88 & 1.01 \\
\hline 99:Q3 & 0.898 & 105,000 & 11,021 & 2,931 & 8,090 & 11,097 & 11,168 & 0.99 & 1.14 & 0.94 \\
\hline 99:Q4 & 0.937 & & 10,663 & 2,566 & 8,097 & 10,598 & 10,847 & 0.98 & 1.00 & 0.98 \\
\hline 00:Q1 & 0.966 & & 11,845 & 2,688 & 9,157 & 10,326 & 10,462 & 1.13 & 1.05 & 1.16 \\
\hline 00:Q2 & 0.979 & & 8,861 & 2,027 & 6,834 & 9,889 & 10,108 & 0.88 & 0.80 & 0.90 \\
\hline 00:Q3 & 0.989 & 115,000 & 9,934 & 2,899 & 7,035 & 9,852 & 9,870 & 1.01 & 1.14 & 0.96 \\
\hline 00:Q4 & 1.011 & & 8,917 & 2,393 & 6,524 & 10,607 & 10,229 & 0.87 & 0.89 & 0.87 \\
\hline 01:Q1 & 1.029 & & 11,694 & 3,043 & 8,651 & 11,056 & 10,832 & 1.08 & 1.06 & 1.09 \\
\hline 01:Q2 & 1.046 & & 11,883 & 2,875 & 9,008 & 11,941 & 11,498 & 1.03 & 0.94 & 1.07 \\
\hline 01:Q3 & 1.080 & 126,000 & 11,731 & 3,479 & 8,252 & 12,458 & 12,199 & 0.96 & 1.11 & 0.91 \\
\hline 01:Q4 & 1.120 & & 12,454 & 3,198 & 9,256 & 12,644 & 12,551 & 0.99 & 1.02 & 0.98 \\
\hline 02:Q1 & 1.173 & & 13,762 & 3,019 & 10,743 & 12,591 & 12,617 & 1.09 & 0.96 & 1.13 \\
\hline 02:Q2 & 1.207 & & 12,628 & 2,732 & 9,896 & 12,400 & 12,496 & 1.01 & 0.86 & 1.06 \\
\hline 02:Q3 & 1.252 & 149,000 & 11,519 & 3,651 & 7,868 & 12,510 & 12,455 & 0.92 & 1.13 & 0.85 \\
\hline 02:Q4 & 1.287 & & 11,692 & 3,355 & 8,337 & 13,035 & 12,772 & 0.92 & 1.01 & 0.88 \\
\hline 03:Q1 & 1.357 & & 14,202 & 3,405 & 10,797 & 13,202 & 13,118 & 1.08 & 0.99 & 1.12 \\
\hline 03:Q2 & 1.420 & & 14,725 & 2,933 & 11,792 & 12,840 & 13,021 & 1.13 & 0.83 & 1.24 \\
\hline 03:Q3 & 1.502 & 192,000 & 12,187 & 4,450 & 7,737 & 12,148 & 12,494 & 0.98 & 1.25 & 0.87 \\
\hline 03:Q4 & 1.535 & & 10,245 & 3,424 & 6,821 & 10,918 & 11,533 & 0.89 & 0.97 & 0.85 \\
\hline 04:Q1 & 1.572 & & 11,436 & 3,457 & 7,979 & 11,018 & 10,968 & 1.04 & 0.96 & 1.08 \\
\hline 04:Q2 & 1.603 & & 9,804 & 2,757 & 7,047 & 11,277 & 11,148 & 0.88 & 0.75 & 0.95 \\
\hline 04:Q3 & 1.638 & 220,000 & 12,587 & 5,026 & 7,561 & 11,585 & 11,431 & 1.10 & 0.96 & 0.95 \\
\hline 04:Q4 & 1.686 & & 11,282 & 3,651 & 7,631 & 12,217 & 11,901 & 0.95 & 0.96 & 0.94 \\
\hline 05:Q1 & 1.734 & & 12,667 & 3,562 & 9,105 & & & & & \\
\hline 05:Q2 & 1.792 & & 12,333 & 3,125 & 9,208 & & & & & \\
\hline No: & & & & & & & & & \\
\hline
\end{tabular}

Notes:

This table presents an example of the procedure used to construct variables used in statistical tests of seasonality and policy influences on demand. The data presented above is for the aggregate Perth housing market. In the statistical tests that follow in Table 2 the same procedure is followed for 19 local government authority areas and the data is 'stacked' to increase the explanatory power of the tests.

1. The first-home price band is derived by deflating the figure of $\$ 220,000$ in $04: Q 3$ by the relevant change in the logarithmic index for the relevant quarterly period. A numerical example is included in the text.

2. The four period moving average (MA) for the first four quarterly periods; $((7,450+8,341+6,902+4,217) / 4)=6,728$.

3. The centred moving average (CMA). For the first period; $((6,728+6,037) / 2)=6,382$.

4. The ratio of transactions for a quarterly period to the CMA, is denoted as the variable $\Phi$. For the first period, $6,902 / 6,382=1.08$. This ratio $\Phi$ is used in parametric tests to test for statistically significant differences in sales volumes for quarterly periods. The periods 04:Q2 and 04:Q3 are shaded as these are the periods specifically tested to assess the impact of the policy initiatives. 
Table 2: Seasonal and policy influences on demand

\begin{tabular}{|c|c|c|c|c|c|c|}
\hline \multicolumn{7}{|c|}{ Part A: Tests for Seasonal Influences on Demand 1988-2005 } \\
\hline \multirow[b]{2}{*}{ Sample } & \multirow{2}{*}{$\begin{array}{l}\text { Mean } \Phi \text { all } \\
\text { periods } \\
N\end{array}$} & \multicolumn{4}{|c|}{$\begin{array}{c}\text { Seasonality } \\
\text { One Sample } t \text { tests } \\
\text { Mean } \Phi \text { for Quarter } t\end{array}$} & \multirow{2}{*}{$\begin{array}{l}\text { One Way } \\
\text { ANOVA } \\
\text { F } \\
\begin{array}{c}\text { Prob. } \\
\text { df }\end{array}\end{array}$} \\
\hline & & \begin{tabular}{|c|} 
Q1 Mean $\Phi$ \\
$(t)$ \\
df \\
\end{tabular} & \begin{tabular}{|c|}
$\begin{array}{c}\text { Q2 Mean } \Phi \\
(t) \\
\text { df }\end{array}$ \\
\end{tabular} & $\begin{array}{c}\text { Q3 Mean } \Phi \\
\text { (t) } \\
\text { Df }\end{array}$ & $\begin{array}{c}\text { Q4 Mean } \Phi \\
\text { (t) } \\
\text { df }\end{array}$ & \\
\hline Full sample & $\begin{array}{l}0.996 \\
1,216\end{array}$ & $\begin{array}{c}1.067 \\
(10.7)^{\star} \\
303\end{array}$ & $\begin{array}{c}0.989 \\
(-1.0) \\
303\end{array}$ & $\begin{array}{c}0.992 \\
(-2.9)^{\star} \\
303\end{array}$ & $\begin{array}{c}0.936 \\
(-9.5)^{\star} \\
303\end{array}$ & $\begin{array}{c}75.3 \\
0.00 \\
1,212\end{array}$ \\
\hline $\begin{array}{l}\text { First-home } \\
\text { price band }\end{array}$ & $\begin{array}{l}0.984 \\
1,216\end{array}$ & $\begin{array}{c}0.961 \\
(-1.9)^{\star} \\
303\end{array}$ & $\begin{array}{c}0.886 \\
(-7.7)^{\star} \\
303\end{array}$ & $\begin{array}{c}1.130 \\
(11.5)^{\star} \\
303\end{array}$ & $\begin{array}{c}0.960 \\
(-2.2) \\
303\end{array}$ & $\begin{array}{c}70.4 \\
0.00 \\
1,212\end{array}$ \\
\hline Other sales & $\begin{array}{l}0.995 \\
1,216\end{array}$ & $\begin{array}{c}1.087 \\
(13.1)^{\star} \\
303\end{array}$ & $\begin{array}{l}1.022 \\
(3.5)^{\star} \\
303\end{array}$ & $\begin{array}{l}.947 \\
(-9.1)^{\star} \\
303\end{array}$ & $\begin{array}{c}0.926 \\
(-10.1)^{\star} \\
303\end{array}$ & $\begin{array}{c}118.6 \\
0.00 \\
1,212\end{array}$ \\
\hline \multicolumn{7}{|c|}{$\begin{array}{l}\text { 1. The variable } \Phi \text { is the ratio of the volume of transactions in a quarterly period to the centred } \\
\text { four period moving average. This procedure is explained more fully in Table } 1 . \\
\text { 2. The one-sample } t \text { test, tests the null hypothesis that the mean } \Phi \text { for a quarterly sample is the } \\
\text { same as the mean } \Phi \text { for the full sample (mean } \Phi \text { all periods). } \\
\text { * denotes statistical significance at a level of } .05 \text { or higher. }\end{array}$} \\
\hline \multicolumn{7}{|c|}{ Part B: Tests for Policy Influences on Demand 1988-2005 } \\
\hline & \multicolumn{6}{|c|}{$\begin{array}{c}\text { Policy Influences } \\
\text { One Sample } t \text { tests } \\
\text { Mean } \Phi \text { for Quarter 2: } 2004 \text { and Quarter 3: } 2004\end{array}$} \\
\hline Sample & $\begin{array}{l}\text { Mean } \Phi \text { all } \\
\text { Q2 periods } \\
\text { N }\end{array}$ & & $\begin{array}{l}2: 04 \\
\text { (t) } \\
\text { df }\end{array}$ & $\begin{array}{c}\text { Mean } \Phi \text { a } \\
\text { Q3 perioc } \\
\mathrm{N}\end{array}$ & & $\begin{array}{l}\text { 3:04 } \\
\text { an } \Phi \\
\text { (t) } \\
\text { Df }\end{array}$ \\
\hline Full sample & $\begin{array}{c}0.989 \\
304\end{array}$ & & $\begin{array}{l}877 \\
3.1)^{\star} \\
18\end{array}$ & $\begin{array}{c}0.992 \\
304\end{array}$ & & $\begin{array}{l}095 \\
7)^{\star} \\
18\end{array}$ \\
\hline $\begin{array}{l}\text { First-home } \\
\text { price band }\end{array}$ & $\begin{array}{c}0.886 \\
304\end{array}$ & & $\begin{array}{l}722 \\
8.4)^{\star} \\
18\end{array}$ & $\begin{array}{c}1.130 \\
304\end{array}$ & & $\begin{array}{l}363 \\
18)^{\star}\end{array}$ \\
\hline Other sales & $\begin{array}{c}1.022 \\
304\end{array}$ & & $\begin{array}{l}951 \\
5.1)^{\star} \\
18\end{array}$ & $\begin{array}{c}0.947 \\
304\end{array}$ & & $\begin{array}{l}963 \\
18 \\
\end{array}$ \\
\hline
\end{tabular}




\begin{tabular}{|c|c|c|c|c|}
\hline \multicolumn{5}{|c|}{ Part C: Tests for Policy Influences on Demand 1999-2005 } \\
\hline \multirow[b]{2}{*}{ Sample } & \multicolumn{4}{|c|}{$\begin{array}{c}\text { Policy Influences } \\
\text { One Sample } t \text { tests } \\
\text { Mean } \Phi \text { for Quarter 2: } 2004 \text { and Quarter 3: } 2004\end{array}$} \\
\hline & $\begin{array}{l}\text { Mean } \Phi \text { all } \\
\text { Q2 periods } \\
\quad \mathrm{N}\end{array}$ & \begin{tabular}{|c|} 
Q2:04 \\
Mean $\Phi$ \\
$(\mathrm{t})$ \\
$\mathrm{df}$
\end{tabular} & $\begin{array}{l}\text { Mean } \Phi \text { all } \\
\text { Q3 periods } \\
\mathrm{N}\end{array}$ & $\begin{array}{l}\text { Q3:04 } \\
\text { Mean } \Phi \\
\text { (t) } \\
\text { Df }\end{array}$ \\
\hline Full sample & $\begin{array}{c}0.984 \\
114\end{array}$ & $\begin{array}{c}0.877 \\
(-12.6)^{\star} \\
18\end{array}$ & $\begin{array}{c}0.996 \\
114\end{array}$ & $\begin{array}{c}1.095 \\
(5.5)^{\star} \\
18\end{array}$ \\
\hline $\begin{array}{l}\text { First-home } \\
\text { price band }\end{array}$ & $\begin{array}{c}0.826 \\
114\end{array}$ & $\begin{array}{c}0.722 \\
(-5.4)^{\star} \\
18\end{array}$ & $\begin{array}{c}1.203 \\
114\end{array}$ & $\begin{array}{c}1.363 \\
(4.1)^{\star} \\
18\end{array}$ \\
\hline Other sales & $\begin{array}{c}1.047 \\
114\end{array}$ & $\begin{array}{c}0.951 \\
(-6.9)^{\star} \\
18\end{array}$ & $\begin{array}{c}0.918 \\
114\end{array}$ & $\begin{array}{c}0.963 \\
(2.1) \\
18\end{array}$ \\
\hline \multicolumn{5}{|c|}{$\begin{array}{l}\text { Notes: } \\
\text { In Parts } B \text { and } C \text { the one-sample } t \text { test, tests the null hypothesis that the mean } \Phi \text { for Q2 or } \\
\text { Q3:2004 is the same as the mean } \Phi \text { for the relevant quarters for the full time series } 1988-2005 \\
\text { (Part B) and also for a shorter time series } 1999-2005 \text { (Part C). } \\
\text { * denotes statistical significance at a level of } .05 \text { or higher. }\end{array}$} \\
\hline
\end{tabular}

\section{RESULTS}

Table 2 is arranged in three parts. The results in Part A are tests for seasonality, Part B for policy influences for the full sample period 1988-2005 and Part C reports results for similar policy tests on a shorter time series 1999-2005. The tests in Part C are used as a control group, as it is possible that patterns of demand and/or relevant first-home price bands in the more recent boom period might vary from earlier market periods that are included in the full sample and this could distort results. The results are reported first for the aggregate market (full sample), then first-home price bands and finally, non-first-home sales or 'other' sales.

The results in Part A confirm the previously established seasonal trends in the Perth housing market (Costello, 2001) but use a longer time series. Part A also extends previous results in that seasonal influences are identified for cheaper housing in the first-home price band and 'other' sales. Interestingly, the seasonal pattern for cheaper properties is markedly different from that observed in the aggregate Perth housing market and for 'other' sales.

In contrast to the aggregate market, the highest demand period for cheaper homes is quarter 3 , even though this is a significantly quieter period for the aggregate market and 'other' sales. Quarters 1 and 2 are characterised by low demand for cheaper properties and the results for quarter 4 are not as pronounced as for the other price segments. Similar tests for 
seasonal influences were also completed for the shorter time series 1999-2005 used in Part $\mathrm{C}$ (results not reported) and very similar seasonal patterns were observed for all price segments.

These varying patterns of demand for cheaper properties are likely to be driven by investment activity for cheaper residential property rather than owner-occupier sales. Whereas aggregate market demand tends to be largely influenced by owner-occupier sales, investment activity and demand variations tend to coincide more with taxation considerations and the financial year. Owner-occupier housing search behaviour tends to correspond closely with summer holiday periods, hence quarter 1 tends to be a high demand period. Investors in cheaper residential property are likely to be influenced by taxation considerations and will base purchasing decisions around tax year periods. These distinct seasonal patterns for different price segments further confirm the need for robust methodologies to be used in the analysis of patterns of demand in housing markets.

The results in Parts B and C confirm that the periods associated with the policy changes are characterised by significant changes in demand. In Q2:2004, it was expected that the announcement of the policy would impact negatively on the demand for cheaper properties. The results confirm that the introduction of the new information on 7 May 2004 had a significant negative impact on the demand for housing in the first-home price band. The results in Table 2 confirm that with the full time series 1988-2005 (Part B), this change is in the order of a decline of $19 \%$ in demand from that observed for other Q2 periods in the time series. When analysing the shorter more recent time series 1999-2005 (Part C), this decline is less significant, around $13 \%$. These results are supported with high levels of statistical significance.

Furthermore, it is evident that the policy announcement also impacted negatively on demand, both within the aggregate Perth housing market and for 'other' sales. While the $11 \%$ decline in demand for the aggregate market can in some part be explained by the firsthome price band influence, the 7\%-9\% decline in demand for the 'other' sales price segment is more instructive. These demand variations in price segments not directly targeted by the policy are likely to be caused by the operational characteristics of housing markets and the contingent nature of many real estate transactions. It is apparent that the announcement of the policy initiatives may have 'stalled' transaction activity by impacting on the necessary 'chains' of transactions that allows cheaper home owners to 'trade up' to more expensive housing.

In Q3:2004, it was expected that the enactment of the policy would impact positively on the demand for cheaper properties. The results confirm that the introduction of the policy on 1 July 2004 also had a significant positive impact on the demand for housing in the firsthome price band. The results in Table 2 confirm that with the full time series 1988-2005 (Part B), this change is in the order of an increase of $21 \%$ in demand from that observed for other Q3 periods in the time series. When analysing the shorter more recent time series 
1999-2005 (Part C), this increase is less significant, around 13\%. Once again these results are supported with high levels of statistical significance.

It is evident that the policy enactment also impacted positively on demand within the aggregate Perth housing market, but there was no significant change for 'other' sales. The $10 \%$ increase in demand for the aggregate market is most likely explained by the firsthome price band influence. While there is no significant influence for other price segments in Q3:2004, it is possible that there might be an increase in demand in later periods due to the lagged influence of the policy, whereby increased sales in the cheaper price bands during Q3:2004 would feed into the 'chains' of transactions enabling the sellers of these properties to 'trade up' during the later periods of 2004 and early 2005.

\section{CONCLUSIONS}

The results of this study confirm that direct intervention by state governments in housing markets through amending conveyance (stamp) duty levels for first-home buyer price segments can have an immediate and significant impact on demand in both the price segments that are the target of policy initiatives and also within the aggregate housing market. The results of this study confirm that the introduction of reduced stamp duty rates for specified cheaper house price segments on July 1, 2004 resulted in an increase in demand of about $21 \%$ to that observed for comparable price segments in the sample period 1988-2005. There was also a lower level increase in demand for the aggregate market.

This study also confirms some important information diffusion effects that have important implications for further policy development. The results indicate that the release of the information on 7 May 2004, almost two months prior to the enactment of the policy lead to a pronounced decline in demand for cheaper housing, and also in other price segments. The implication for policy makers is clear in that information of this type impacts significantly on demand in two ways; first, a significant decrease in demand through the 'news' content of government sponsored incentives at a later date and second, the significant increase in demand as the value of the government sponsored incentives become available to the market.

If it is assumed that the general objective of the policy initiatives was to increase affordability levels for first-home buyers, then policy makers need to be aware of the influence of information of this type in the market prior to the introduction of a policy. The significant variations in demand in two quarterly periods will eventually impact on prices and further research is required to examine whether the stamp duty reductions are eventually capitalised into higher prices for cheaper housing, thus negating the initial objectives of the policy.

In addition, policy makers need to be aware of the wider reaching implications on housing demand through policy initiatives of this type. Many housing transactions are contingent in 
nature with the cheapest price segments being an important first link in many of the 'chains' of housing transactions that allow participants to 'trade up' in the housing market. The results in this study indicate clearly that the information content of the May 7 announcement impacted significantly in 'stalling' demand, not only for cheaper housing but also for the aggregate market and non-first-home price segments.

This study is the first stage in analysing the influence of these policy initiatives. The results reported here are for demand influences on housing in the Perth metropolitan region. Further research is required as to the influence of these policy initiatives within regional Western Australia and also within vacant land markets. The cheaper house price levels in regional areas suggest that the influence of the policy might be more pronounced in these areas. Finally, the important issue of how these policy initiatives impacted on price changes both within cheaper price segments and the aggregate housing market must be examined to understand the full influence and effectiveness of these measures in promoting affordability in first-home markets.

\section{REFERENCES}

Berry, J., McGreal, S. Stevenson, S., Young, J. (2001). "Government Intervention and Impact on the Housing Market in Greater Dublin", Housing Studies, Vol 16 (6), 755-769.

Case, K. E., and Shiller, R.J. (1989). "The Efficiency of the Market for Single-Family Homes", The American Economic Review, Vol 79, 125-137.

Case, K.E., and Shiller, R.J. (2003). "Home-Buyers, Housing and the Macro-Economy", Reserve Bank of Australia Conference on Asset Prices and Monetary Policy, Sydney 18-19 August, 2003.

Costello, G., (2000). "Pricing Size Effects in Housing Markets", Journal of Property Research, Vol 17(3), 203-219.

Costello, G., (2001). "Seasonal Influences in Australian Housing Markets", Pacific Rim Property Research Journal, Vol 7(1), pp47-60.

Fama, E. F. (1970). "Efficient Capital Markets: A Review of Theory and Empirical Work", Journal of Finance, Vol 25, 383-420.

Gatzlaff, D.H., and Tirtiroglu, D. (1995). "Real Estate Market Efficiency: Issues and Evidence", Journal of Real Estate Literature, Vol 3, 157-189.

Leung, C.K., Leong, Y.C., and Wong, S.K., (2006). "Housing Price Dispersion: An Empirical Investigation", Journal of Real Estate Finance and Economics, Vol 32 (3), 357. 
Poterba, J.M. (1984). "Tax Subsidies to Owner-occupied Housing: an Asset Market Approach”, Quarterly Journal of Economics, Vol 99(4), 729-752.

Schwann, G.M., and Chau, K.W. (2003). "News Effects and Structural Shifts in Price Discovery in Hong Kong", Journal of Real Estate Finance and Economics, Vol.27 (2), 257.

Wood, G. A. (1990). "The Tax Treatment of Housing, Economic Issues and Reform Measures", Urban Studies, Vol 27(6), 822-829.

\section{Acknowledgement}

The author gratefully acknowledges the Western Australian Valuer General's Office for providing the data used in this paper. 